This manuscript is published in Eurasian Geography and Economics.

https://doi.org/10.1080/15387216.2019.1707103

Book Review

\title{
Pseudo-public space in Chinese shopping malls: rise, publicness and consequences
}

by Yiming Wang

\author{
Maurice Yip \\ Institute of Geography and Sustainability, University of Lausanne \\ KwanChung.Yip@unil.ch \\ $* * *$
}

This research monograph, published in Routledge Complex Real Property Rights Series, aims to contribute an analysis of the privatized and commercialized urban space in China to the debates in property rights research. Yiming Wang defines the publicly accessible and privately managed space, lying inside the property boundary of the commercial complex, as pseudo-public space.

As hinted by its subtitle, this book presents Wang's empirical findings that neoliberal capitalism led to the rise of pseudo-public space in China in recent three decades. The interplay between capital investors, the state, and the customers, within neoliberal capitalism, influences the publicness of those spaces. As a result, the rise of pseudo-public space brings up socio-spatial, economic and environmental consequences for China. Besides, Wang attempts to contribute to the theoretical debates about whether the privatization of urban space would lead to the end of public space. Wang considers two schools of property rights: the conventional school has a pessimistic view that privatization harms public interests, and the natural rights school optimistically suggests privatization helps create new forms of public life. Wang criticizes both sides for considering publicness as a binary concept with a clear public/private distinction. Instead, urban space should be understood as a continuum and relativities space, and thus refreshing the understanding of property rights involved. This theoretical standpoint shapes how Wang develops his 'scoring' methodology to assess the publicness of urban space, its 'more public' and 'more private' features.

Wang organizes this book in six chapters and two appendices. In chapter 1, Wang opens this book with the great disparities between the urbanization processes in China and the West. Four distinctive 
characteristics of Chinese new urbanism were identified: (i) urbanization of an unprecedented speed within three decades, (ii) huge investment in real property development, (iii) marketization of urban land under Chinese neoliberalism, and (iv) qualitatively differentiated politicaleconomic and social-cultural contexts. Given these unique Chinese features, understanding 'the publicness of the city, and unique institutional and legal arrangements' (5) is central to analyzing the production of new urban spaces in China, particularly 'those outdoor open spaces in and around Chinese shopping malls' (8). Wang, therefore, seeks to examine three major issues in this book: (i) the historical and institutional changes causing the rapid emergence of pseudo-public space, (ii) the publicness of those space and how it influences the publicness of contemporary Chinese cities, and (iii) the consequences of those pseudopublic space and possible policy responses to new urban changes.

Chapter 2 Understanding Spatial Transformation develops the approach and method to examine spatial transformation. Wang reviews the literature on the political economy of capitalist urbanization, mainly drawing from the works of Henri Lefebvre and David Harvey, and finds that, while public space serves as the public sphere in modern urban civil societies, it is also affected by the powerful capitalism for capital circulation and accumulation. Particularly after the rise of neoliberalism, 'because of the existence of private property rights in those new urban spaces, the boundaries between "public" and "private" are becoming more and more blurred in cities' (30), argues Wang. That this fuzziness was ignored becomes Wang's critique of the literature and prompts him to propose a continuum property rights approach that considers twelve dimensions of publicness. Fieldwork and 'scoring' methods are built upon this approach. An extended literature review of the concept of publicness is elaborated in Appendix I.

Findings of pseudo-public space are presented in chapters 3 to 5, discussing its rise, publicness and consequences respectively. Chapter 3 The Rise of Pseudo-Public Spaces argues neoliberalism has influenced the land and property reforms during the reform era and explored the institutional and legal changes at different scales for promoting economic growth, reducing the governments' burden and favoring capital investors. Those changes, including decentralization to local states, desirable planning codes and transfers of land use rights to private hands, rapidly facilitated private development projects in China. Wang suggests that, confronting with the online retailing activities, capital investors provide space for public use in those private shopping malls to attract customers. To show that pseudo-public spaces are neither absolutely public nor private, Chapter 4 discusses two cases of pseudo-public space, namely Xintiandi in Shanghai and Nanping Wanda Plaza in Chongqing, and 
compares them with two publicly owned spaces in both cities. Triangulating with qualitative methods of analyzing the rules and regulations governing the use of spaces and field observations, Wang employs the 'scoring' method to quantitatively assess the publicness of them. Results show pseudo-public spaces are less public, while they still serve as important public places for people's everyday life. The 'scoring' result of the other eight cases of pseudo-public space which are not discussed in the main text is presented in Appendix II.

Chapter 5 Consequences of Pseudo-Public Spaces discusses some impacts of the pseudo-public space on Chinese economic development as the driving force in capital circulation and some indirect environmental problems such as construction waste and air pollution. Perhaps most notably, Wang presents the interviews with two Chinese people to illustrate the urban transformation from the demise of 'work-unit' to the rise of 'pseudo-public space', during which people changed the ways and venues of their social life, and its socio-spatial consequences in terms of gentrification. Some general policy suggestions were made toward flexible legal arrangements of property rights and restructuring the land-based public finance. Chapter 6 summarizes the arguments and suggests future research to enlarge sample sizes, refine the 'scoring' indexes and consider more demographic and socio-economic characteristics of people using pseudo-public space.

Following my reading of this book, I appreciate this book because, firstly, it fully attained its objective to address the three major issues and successfully raised awareness of new questions for further theoretical enquiries. Secondly, I find another strength of this book in the up-to-date empirical investigation of Chinese cities, which makes a significant contribution to urban China research. Wang conducted fieldwork in ten pseudo-public spaces in five Chinese cities, whose selection fits the research objectives well, although the actual way of executing the 'scoring' method is ambiguous even with an attempt to clarify in the appendix. Wang presents the fieldwork results with useful photos and maps. Photos in chapters 4 and 5, for example, enable readers to conveniently grasp a visual impression of the social life in pseudo-public spaces. Maps in chapter 4 spatially represent the property boundaries, surveillance and policing issues which are central to analyzing public space. These findings from the ground constitute substantial empirical knowledge. Yet, I wondered if the remaining eight sites could be detailly discussed to favor a more sufficient empirical documentation of Chinese pseudo-public space.

Despite its empirical achievements, I feel this book falls down on some conceptual shortcomings. While the theoretical framework rightfully considers the working of capital in producing new form of urban space in 
China (chapter 2), its apparent weakness is the neglect of the state and certain Chinese characteristics of property rights, especially when this framework is intended to understand China, where a 'particular sociopolitical and economic context' (6) is identified. After reading the whole chapter 1, which emphasizes the peculiarities of the political, economic and social context of urban China based on the academic literature and the empirical factual account, readers would expect a better alternative approach to examine this distinct urban transformation. However, the theoretical framework and the analysis in the subsequent chapters ended up with the universally taken-for-granted notion of neoliberal capitalist urbanization. The recognized disparities are not reflected in the theoretical framework. Readers inevitably keep puzzling the same question while reading the remaining chapters discussing urbanization under neoliberal capitalism: how is the Chinese state unique?

Even though the theoretical framework focuses on capitalist urbanization and property rights debates, I struggled to comprehend some assertions. Wang tends to differentiate between two bodies of scholarship, one led by Lefebvre and Edward Soja, another led by Harvey (29), and in his words, 'putting space first makes Lefebvre significantly different from David Harvey, who tends to choose social processes, rather than space, as his primary interpretative viewpoint' (26). Wang even attempts to distinguish between Lefebvre's 'spatio-social relations', Harvey's 'socialspatio relations', and other political economists' 'socio-spatial dialectic' (66). For sure there could always be potential to freshen the prevailing conceptions of spatiality and social processes, but Wang needs to clearly clarify the differences between his understandings of 'spatio-social' and 'social-spatio' and their theoretical implications.

Because of my personal interest in property, I am inspired by Wang's recognition that property rights can be thought of a continuum. I was keen to see how the Chinese case can advance the property rights debates (10), especially those about common property and private property. Although the debates appear repeatedly (cf. 114), more discussion is needed instead of recapping the western literature. Moreover, Wang's account of property rights debates can be enriched by considering some established works on China, including those by the legal scholars.

Comparing with other recent works on Chinese public space, Wang's book undeniably provides valuable and useful empirical research and opens the door to potential theoretical advancements in property studies in the Chinese context. 